\title{
Psychometric evaluation of the German version of a social support scale of FAFHES (Family Functioning, Family Health and Social Support)
}

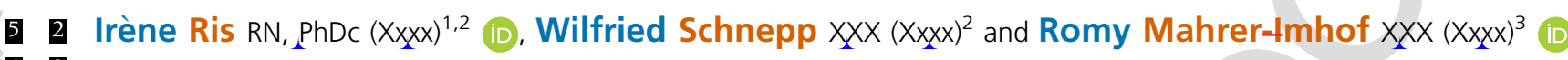 \\ $43{ }^{1}$ Institute of Nursing, Zurich University Applied Sciences, Winterthur, Switzerland, ${ }^{2}$ Witten/Herdecke University, Witten, Germany and \\ ${ }^{3}$ Nursing Science \& Care Ltd, Winterthur, Switzerland
}

Scand J Caring Sci; 2019

Psychometric evaluation of the German version of a social support scale of FAFHES (Family Functioning, Family Health and Social Support)

Background: Family members often need to be supported in informal care of the elderly and desire to be involved into care planning and decision-making. Valid and reliable instruments are needed to measure how family members perceive the care and support they receive from nurses for older family members living at home.

Aim: The purpose of this study was to translate the 20item social support scale of the Family Functioning, Family Health and Social Support (FAFHES) questionnaire from English to German and test the validity and reliability of the scale among Swiss-German-speaking family caregivers of home-dwelling elderly people who receive home healthcare services.

Methods: A cross-sectional study was conducted to test the empirical and psychometric properties of the translated and culturally adapted version of the social support questionnaire. A factor analysis with the principal component analysis PCA was used to test construct validity.
The internal consistency of items was measured with the Cronbach's alpha coefficient.

Results: After a rigorous translation process the original 20-item questionnaire was adapted into a 19-item version and tested with family caregivers $(n=207)$ of home-dwelling elderly. Psychometric testing of the German version of the social support questionnaire revealed that the three factors - affirmation, affect and concrete aid - were congruent with the original questionnaire. The accounted variance was $79.5 \%$ and the internal consistency determined by the Cronbach's alpha was 0.973 . Conclusion: The German version of the social support scale of the FAFHES questionnaire is a valid and reliable instrument to assess family perceived support on three dimensions - affirmation, affect and concrete aid received from nursing professionals. The questionnaire should be tested further in other German-speaking populations.

Keywords: community care, family caregiver, involvement into care, psychometrics, questionnaire, social support.

Submitted 15 March 2019, Accepted 24 March 2019

\section{Introduction}

The ageing of society will worldwide result in more people over the age of 65 years. By 2050, the proportion of people over 60 years of age will grow from $11 \%$ to $22 \%$, and the number of persons 80 years and older will be 26 times higher than today (1). Older people experience certain health problems at higher rates than younger people, such as cancer, hip fracture, stroke or dementia, and older adults are more likely to have co-morbid conditions

\section{Correspondence to:}

Irène Ris, Zurich University of Applied Sciences, Institute of

Nursing, Technikumstr. 71

8401 Winterthur, Switzerland.

Email: risi@zhaw.ch which lead to a higher need for care and support (2). Therefore, healthcare systems together with familial informal care systems will face increasing challenges in the near future (3-5). It is expected that future care arrangements in the community will represent a greater mix of informal and formal care $(4,6-8)$. Family members will play a pivotal role in supporting older relatives in need, allowing them to continue to live at home and prevent long-term institutional care (9). In Switzerland, it is estimated that $63 \%$ of people over 65 years of age who receive professional nursing care at home due to physical, mental, cognitive and/or functional limitations today are simultaneously supported by family caregivers (10).

A considerable body of knowledge about the support needs and desired involvement of family caregivers into 
care planning and decision-making exists from qualitative research. The importance of family support and involvement in care processes has expanded lately beyond the context of families with children (11). Research has been conducted with family members in different care settings, such as of hospitalised patients at time of discharge (1113), in hospices (12), nursing homes (14) and in ambulatory care $(15,16)$. Family members are often seen as pivotal resource in providing care to the elderly, but are not considered as partners in the healthcare system (17). Being a partner means to have an ongoing, sustained relationship with nurses. Additionally, family members have important information about the elderly's health, functional problems and preferences. Family involvement is therefore important, and the knowledge imparted needs to be included in the decision-making regarding care and treatment $(16,18,19)$. Studies with families of older people living at home, however, are scarce (11, 20).

Social support towards family members and involvement into care relates to communication, decision-making and reciprocity. These terms might be used interchangeably. Social support is defined as a mutually influential relationship between the healthcare provider (such as nurses) and healthcare utiliser, in which case the family is seen as an equal member in a free and agreed climate $(21,22)$. Involvement is defined as the act of taking part in something (23). Derived from this general definition, involvement into care process includes the planning, delivery, management and continuous improvement of care by having an active partnership in order to be effective in delivering home health services. Therefore, home care nurses need to establish an active partnership with both the family caregiver and the care receiver.

Recent research investigated involvement of family caregivers. However, involvement has been explored from different perspectives and with different conceptualisations.

First, involvement was operationalised as the number of caregiving tasks performed and the time the family caregiver spent performing towards the care receiver (2426).

Second, family involvement was investigated from the perspective of the healthcare professionals (27-30). Family member and healthcare provider perceptions of family support and involvement have been found to be incongruent $(31,32)$. Third, involvement was operationalised as the families' perception of the support received from nurses. Two instruments have been developed based on a family system nursing approach. They cover the reciprocity of support and involvement. Both have been psychometrically tested. The Iceland Family Perceived Support Questionnaire (ICE-FPSQ) measures the concept 'family perceived support' derived from the Calgary
Family Intervention Model (CFIM). The instrument measures emotional and cognitive, but not the behavioural domains of support (33). The second instrument, the Family Functioning, Family Health and Social Support (FAFHES) questionnaire, consists of three scales that measure family function, family health and perceived social support provided by nurses $(34,35)$. For the scale 'social support', Khan and Antonicci's (36) theoretical framework of the 'convoy model of social relations' was used, leading to the three domains of support. First, emotional support refers to appreciation, admiration, respect or love and a sense of security. This domain is conceptualised as 'affective' support. The second domain, 'affirmation', describes reinforcement, feedback and help to the individuals to find a solution. The third domain is 'concrete aid', such as spending time helping someone with tangible support, for example organising services and financial means $(36,37)$. The FAFHES instrument was initially developed to assess families of cardiac patients $(35,37)$. Since then the instrument has been further developed and used in a variety of settings as well as in different populations, including families with children or older people living at home $(7,38,39)$. Moreover, the instrument has been translated and tested in other languages including Danish, Estonian and Russian $(23,40)$.

As part of an ongoing study in the German-speaking part of Switzerland, the social support scale of the FAFHES questionnaire was selected for use in the assessment of family caregivers' perception of perceived social support and involvement by home healthcare nurses. For the purpose of this study, the 20-item social support scale of the Family Functioning, Family Health and Social Support (FAFHES) has been translated from English into German. The validity and reliability of the scale has been tested among Swiss-German-speaking family caregivers of home-dwelling elderly people who receive home healthcare services, and this article reports the results.

\section{Method}

First, the scale Social Support of the FAFHES has been translated according to the Guidelines of Beaton, with six steps (41). Second, the psychometric properties of the German version were tested.

\section{The German Version of the Social Support Questionnaire}

The social support scale compromises 20 items and operationalises the three domains of the convoy model (34-36). The scale measures affect with eight items, affirmation with seven items and concrete aid with five items on a Likert scale ranging from 1 (definitely disagree) to 6 (definitely agree). With permission from the copyright holders to use, translate and modify the social support scale of the FAFHES questionnaire, the original English 
version was translated into German. The aim of the translation process was to have a questionnaire, which was semantically equivalent to the original instrument and comprehensible to the respondents.

Guidelines for the process of cross-cultural adaptation of self-report measures, which contains six stages, were applied (41). First, two persons translated from the original language to the target language. Both produced a written translation, along with a report where they provided comment and highlighted challenging phrases or uncertainties. Second, they worked together to produce a synthesised result, while documenting the issues addressed and how they were resolved. Third, two bilingual native English-speaking nurses translated the questionnaire back to the original language. In the fourth stage, a committee consolidated all the versions of the questionnaire, to verify the semantic equivalence of the questionnaire between the English and German versions. Experiential equivalence was reviewed to ensure that expressions had an equivalent meaning in the target version. Conceptual equivalence recognises that words may hold different conceptual meaning between cultures. After checking for all equivalences, the face validity was tested in the fifth stage. Face validity refers to whether an instrument appears to measure the intended construct (42). Cognitive debriefing interviews in the field assessed the questionnaire according to comprehensibility, acceptance and face validity with three female and one male family caregiver. During the interview, misunderstandings and discrepancies were noted. The last stage included the final adaption of the German version to integrate the interpretations of the respondents' items.

\section{Setting, recruitment and ethical approval}

The questionnaire was tested among family members of older adults who receive services from a home health nursing organisation in a major city in the Germanspeaking part of Switzerland.

For recruitment, a home health care organisation informed a total of 1257 care receivers over the age of 65 years that their family members who were listed in the care receiver files would be invited in writing to participate in the study. The care receivers were informed that they could actively oppose an invitation of their family member within a week.

All persons who considered themselves to be family of the care receiver because they had emotional, biological or economic ties to the care receiver were eligible to participate (43). Some care receivers had more than one family member listed on their file. Both the participants and the care receivers were assured that all participation in the process was voluntary and anonymous. The relevant ethics committee (KEK-ZH-BASEC-Nr. Req-201600288) in the Canton of Zürich approved the study.

\section{Data collection}

Between July 2016 and January 2017, a total of 1672 family members received an information letter and the questionnaire. In addition to the translated questionnaire, demographics of the family caregivers and the care receivers (i.e. such as age, sex, marital status, education level, occupational status, living situation and relation to care receiver) as well as the care situation of the care receivers (numbers of service hours/week, and kind of professional services such as nurses and/or domestic support persons) were assessed.

\section{Data cleaning and analysis}

Data were entered into the IBM SPSS Statistical Program version 24. In a second step, data were checked for patterns of missing data. According to Kuckartz (44), questionnaires with less than $20 \%$ missing data points were completed using multiple imputation method, questionnaire with more than $20 \%$ missing data on all items were excluded from analysis (45).

Descriptive statistics including frequency counts (n), means and standard deviation (SD) were calculated to summarise the sociodemographic of the care receiver and family caregiver. The assumption of normality was accepted $(n>200)$ when skewness values were larger than 2 or kurtosis were larger than $7(46,47)$. Factors with principal component analysis (PCA) with varimax rotation was used. The Kaiser-Meyer-Olkin (KMO) statistics and the Bartlett tests were checked, which indicated that data were suitable for factor analysis. Acceptable model fit is given for $\mathrm{KMO} \geq 0.80$ and the Bartlett test, p-value $<0.05$ (46).

The questionnaire had neither been tested in a German version nor with family caregivers of older home-dwelling persons. Therefore, an exploratory factor analyses (EFA) was chosen as the preferred method (46). The aim of the PCA was to get the best factor solution based on the given criteria. Factors were selected if eigenvalues were greater than 1, or if there was change in slope of the scree plot. As suggested in many method papers, an eigenvalue $>0.70$ has been considered as still being sufficient as factor loading $(46,48,49)$. For interpreting the factor item loadings, the rule of thumb was applied that a minimum loading for a sample for 200 should be $\geq 0.36$ for a level of significance of 0.01 (two-tailed) and if the variables loadings are $\geq 0.55$ (30\% overlapping variance) it is considered as good, $\geq 0.63$ as very good $(40 \%$ overlapping variance) and $\geq 0.71$ as excellent (50\% overlapping variance) (46). Communalities of items measure the proportion of each variable's variance that can be explained by the factors. The closer the communality is to 1 , the better the variable is explained by the factor. Communalities are considered to be $\geq 0.3$ (50). The reported variance per factor was set to explain a 
minimum of $5 \%$. The factor model chosen also had to have a meaningful content. Once the best factor structure was identified in the data, internal consistency was tested with Cronbach's alpha. For the new instrument to be conceptually congruent, a Cronbach's alpha coefficient of 0.70 or higher is needed for each factor and for the instrument as a whole (51).

\section{Results}

Translation, cognitive interviewing and adaptation

The translators were in agreement with most items, and although some German words were occasionally different it was determined that they had semantically equivalent meaning. Since the survey was originally designed for hospitalised cardiac patients, the original questionnaire had to be adapted for general patients in the community-dwelling care setting. Therefore, a few words in items $(1,8,10,11$ and 12) had to be conceptually modified (Table 1). The expression cardiac was extended more generally as disease, and one item 'Our family has received adequate information about the risks of sauna bathing to the patient' was omitted, as sauna bathing is not an established habit for elderly in Switzerland. The cross-cultural adapted version was then back translated by two native English-speaking nurses.

Some words differed according semantic and idiomatic equivalence. One item had to be adapted in order to achieve experiential equivalence from, 'Our family received adequate information about what to consider regarding the patient's mental exertion' to 'our family received adequate information about what to consider regarding psychological stress of our family member'. The

Table 1 Modification and adaption of items

1. We are satisfied with how nurses involved the (patient)* care

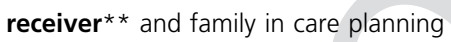

5. We are satisfied with the amount of discussion about the patient's condition during (hospitalisation) care at home

8. Our family received adequate information about (a cardiac patient's diet) nutrition of our family member

10. Our family received adequate information about what to consider regarding (the patient's mental exertion) to psychological stress of our family member

11. Our family has received adequate information about (how cardiac illness affects sexual life) the impact the health condition can have on sexuality

12. We have been sufficiently encouraged by nurses to become involved (in the patient's hospital care) in the care provided at home

*Expression in parenthesis $=$ original questionnaire.

**Expression in bold font $=$ adapted. cognitive debriefing interviews with four family members were conducted to assess ambiguities of family members when paraphrasing the questions. The results from the debriefing process were eventually incorporated in a final version of the questionnaire.

\section{Demographics}

A total of 243 questionnaires were returned which corresponds to a response rate of $16.4 \%$. After data cleaning with multiple imputation and deletion of those questionnaire which had more than four unanswered items $(\mathrm{n}=36)$, a total of 207 questionnaire remained for the analysis.

In Table 2, the characteristics of the family caregivers are summarised. The median age of family caregivers was 60.5 years. Half of the participants were still employed. The range of duration of caregiving was between 2 months and 38 years. The average duration of caring was 5.1 years and the median was at 3 years. The mean time of caregiving per week was assessed at 18.85 hours, with a median of 6 hours per week. Almost one-fourth were partners or spouses of who lived with the care receiver. Three quarters lived apart from the care receivers, of which more than half were family caregivers (daughters, sons or siblings), one quarter were friends, neighbours or others.

In Table 3, the characteristics of care receivers are listed. The mean age was 85 years old (median 86), and the majority were women $(69.6 \%)$. The amount of professional care received by the older person per week was assessed by the family caregiver as well. While one-fifth could not specify the amount of professional services provided per week, the remaining 165 caregivers reported an average of about 4.7 hours per week, with a median of 3 hours. About $36.8 \%$ of the care receivers used nursing care only, $40.6 \%$ used both nursing and domestic care and $14.5 \%$ received only domestic support. In $6.3 \%$ of the cases the family caregiver did not know what kind of support was being provided.

\section{Social Support Questionnaire}

In Table 4, social support items distribution and item correlation are shown. Regarding the symmetry of the data, negative skewness (range -1.056 to 0.840 ) and kurtosis (range 0.210 to -1.331 ) were tolerable. Average interitem correlation was 0.653 , with a minimum 0.373 and maximum of 0.895 . Item-total correlation ranged from 0.58 to 0.878 , indicating good-to-high correlation. The KMO measure of sampling adequacy was 0.953. The Bartlett's test was significant (Chi-Quadrat (117) $=35$ $65.929, \mathrm{p}=0.000)$. Both values support the appropriateness of factor analysis for this data. 
Table 2 Family caregiver characteristics (n 207)

\begin{tabular}{|c|c|c|c|c|c|}
\hline Variables & $\begin{array}{l}\text { Completers, } \\
n\end{array}$ & $n$ & $\%$ & Mean & $S D$ \\
\hline Age, years & 204 & & & 62.45 & 11.342 \\
\hline Sex & 204 & & & & \\
\hline Female & & 128 & 61.8 & & \\
\hline Male & & 76 & 36.7 & & \\
\hline Unknown & & 3 & 1.4 & & \\
\hline Marital status & 203 & & & & \\
\hline $\begin{array}{l}\text { Married/ } \\
\text { partnership }\end{array}$ & & 145 & 70.0 & & \\
\hline Divorced & & 25 & 12.1 & & \\
\hline Widowed & & 10 & 4.8 & & \\
\hline Single & & 22 & 10.6 & & \\
\hline Education level & 204 & & & & \\
\hline Obligation school & & 12 & 5.8 & & \\
\hline Apprenticeship & & 96 & 46.6 & & \\
\hline High school & & 11 & 5.3 & & \\
\hline Higher education & & 45 & 16.4 & & \\
\hline University & & 34 & 16.4 & & \\
\hline Other & & 5 & 2.4 & & \\
\hline Occupational status & 207 & & & & \\
\hline $\begin{array}{l}\text { Employed } \\
\text { (hour per week) }\end{array}$ & & 108 & 52.2 & 32.89 & 13.48 \\
\hline Retired & & 79 & 38.3 & & \\
\hline Not employed & & 18 & 6.9 & & \\
\hline Other & & 2 & 1.0 & & \\
\hline Care history in month & 185 & & & 62.64 & 64.6 \\
\hline Care $\mathrm{h}$ per week & 179 & & & 18.85 & 35.1 \\
\hline Living situation & 202 & & & & \\
\hline $\begin{array}{l}\text { Living with care } \\
\text { receiver }\end{array}$ & & 48 & 23.2 & & \\
\hline $\begin{array}{l}\text { Living apart from } \\
\text { care receiver }\end{array}$ & & 154 & 74.4 & & \\
\hline $\begin{array}{l}\text { Relation to } \\
\text { care receiver }\end{array}$ & 207 & & & & \\
\hline Partner & & 38 & 18.4 & & \\
\hline Daughter/son & & 111 & 53.6 & 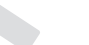 & \\
\hline Sibling & & 6 & 2.9 & & \\
\hline $\begin{array}{l}\text { Friend/ } \\
\text { neighbour/other }\end{array}$ & & & 25.1 & & \\
\hline
\end{tabular}

In the factor analysis with all 19 items three factors were rotated. The results of the three-factor solution with a total variance of $79.6 \%$ are shown in Table 5 . The first two factors showed an eigenvalue $>1.0$, the third factor was 0.95 which was slightly lower than 1.0, but still higher than an eigenvalue of $>0.70$ which has been defined as cut-off point (46). All communalities of the items were $0.67-0.88$ which means none of the 19 items had to be extracted.

The first factor of the three-factor solution consisted of seven items with factor loadings ranging from 0.71 to 0.88 and all items purported to measure affirmation accounted for a variance of $67.42 \%$. Eight items were loading on the second factor affect. These items
Table 3 Care receiver characteristics

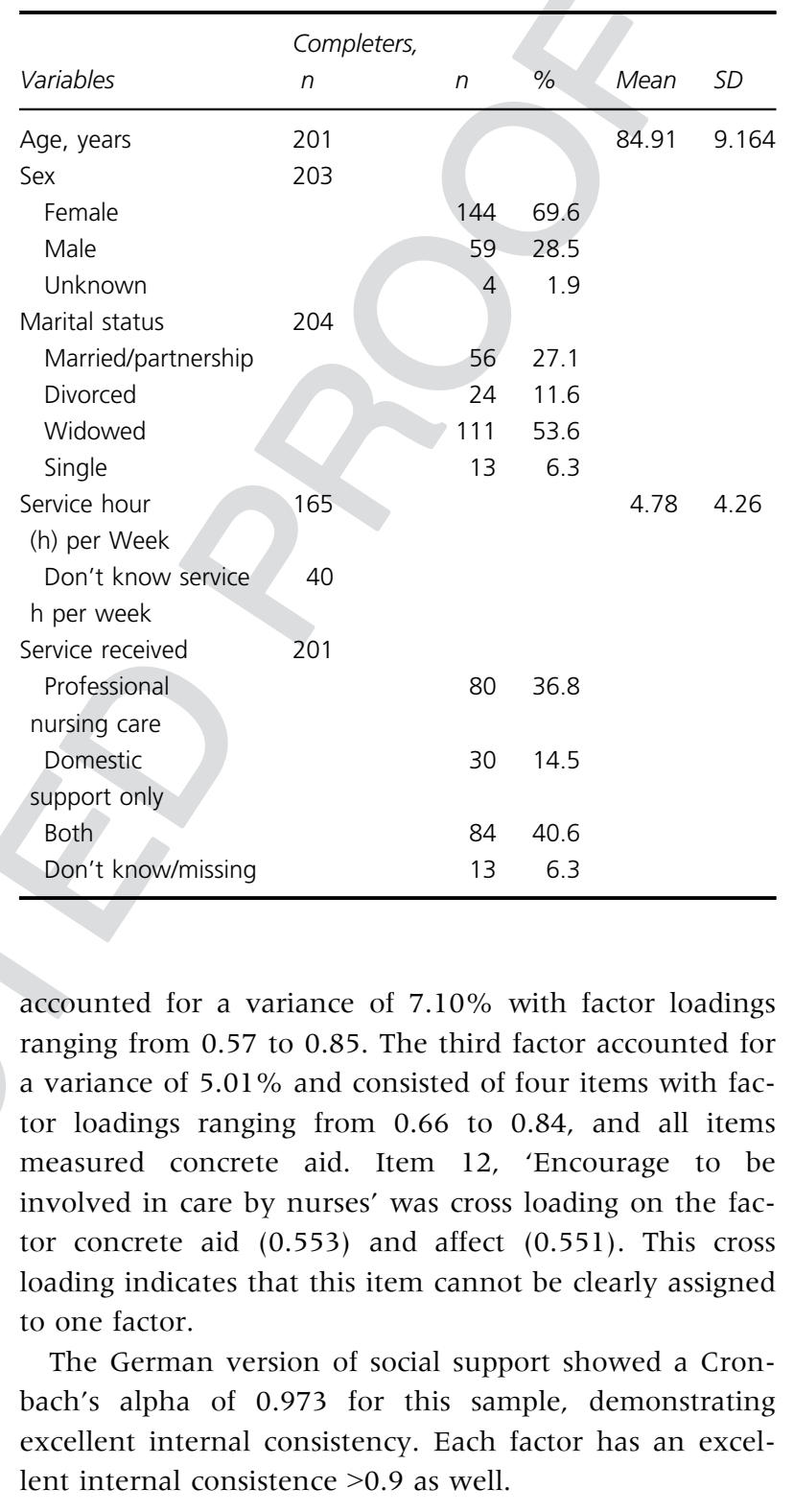

\section{Discussion}

The aim of this study was to attain a German language version of the social support scale of the FAFHES questionnaire and test the validity and reliability of the scale among Swiss-German-speaking family caregivers of home-dwelling elderly people receiving home healthcare services.

The response rate of $16.4 \%$ in this study was low, but more than double the rate $(7.8 \%)$ of an another Swiss study also recruiting family caregivers in similar care situations (52). Gender and age in the sample in our study were comparable with other studies $(7,52,53)$. Nearly two-thirds of family members were women involved in caring for the older person at home. Feminist analysis 
Table 4 Item analysis for the German translation of the FAFHES Social Support Scale $(n=207)$

\begin{tabular}{|c|c|c|c|c|c|c|c|}
\hline \multirow[b]{2}{*}{ Items } & \multirow[b]{2}{*}{$\begin{array}{l}\text { Item-total } \\
\text { correlation }\end{array}$} & \multicolumn{6}{|c|}{ Distribution of the item response (\%) } \\
\hline & & $\begin{array}{l}\text { Definitely } \\
\text { disagree }\end{array}$ & Disagree & $\begin{array}{l}\text { Somewhat } \\
\text { Disagree }\end{array}$ & $\begin{array}{l}\text { Somewhat } \\
\text { agree }\end{array}$ & Agree & $\begin{array}{l}\text { Definitely } \\
\text { agree }\end{array}$ \\
\hline $\begin{array}{l}1 \text { We are satisfied with how nurses involved the care } \\
\text { receiver and family in care planning }\end{array}$ & 0.778 & 5.3 & 8.7 & 6.3 & 15.5 & 40.1 & 24.2 \\
\hline $\begin{array}{l}2 \text { Our family received sufficient explanation of what will } \\
\text { happen in the care of our family member }\end{array}$ & 0.869 & 5.3 & 8.7 & 6.3 & 14.0 & 41.1 & 24.6 \\
\hline $\begin{array}{l}3 \text { We received sufficient counselling in matters related to } \\
\text { our family member's care }\end{array}$ & 0.813 & 8.2 & 9.2 & 6.8 & 14.0 & 41.5 & 20.3 \\
\hline $\begin{array}{l}4 \text { We have been sufficiently engaged in discussions about } \\
\text { the ill family members' course of illness }\end{array}$ & 0.817 & 11.1 & 11.1 & 7.7 & 19.8 & 33.3 & 16.9 \\
\hline $\begin{array}{l}5 \text { We are satisfied with the amount of discussion about } \\
\text { the patient's condition during care at home }\end{array}$ & 0.878 & 7.7 & 9.2 & 11.1 & 20.3 & 34.8 & 16.9 \\
\hline $\begin{array}{l}6 \text { We are satisfied with the amount of discussion about } \\
\text { the progress of care }\end{array}$ & 0.754 & 9.2 & 10.1 & 12.1 & 16.9 & 35.3 & 16.4 \\
\hline $\begin{array}{l}7 \text { We have received sufficient explanation of treatment } \\
\text { options for our family member }\end{array}$ & 0.726 & 8.2 & 10.1 & 13.0 & 14.0 & 35.7 & 18.8 \\
\hline $\begin{array}{l}8 \text { Our family received adequate information about nutri- } \\
\text { tion of our family member }\end{array}$ & 0.812 & 13.5 & 14.5 & 12.6 & 15.0 & 31.9 & 12.6 \\
\hline $\begin{array}{l}9 \text { Our family received sufficient explanation of what kind } \\
\text { of exercise the ill family member can take }\end{array}$ & 0.720 & 12.6 & 15.0 & 15.9 & 14.5 & 30.0 & 12.1 \\
\hline $\begin{array}{l}10 \text { Our family received adequate information about what } \\
\text { to consider regarding to psychological stress of our } \\
\text { family member }\end{array}$ & 0.645 & 8.8 & 18.4 & 18.4 & 15.0 & 21.3 & 8.2 \\
\hline $\begin{array}{l}11 \text { Our family has received adequate information about } \\
\text { the impact the health condition can have on sexuality }\end{array}$ & 0.580 & 37.7 & 26.6 & 9.2 & 13.0 & 9.2 & 4.3 \\
\hline $\begin{array}{l}12 \text { We have been sufficiently encouraged by nurses to } \\
\text { become involved in the care provided at home }\end{array}$ & 0.725 & 14.5 & 19.8 & 11.6 & 15.5 & 25.6 & 13.0 \\
\hline $\begin{array}{l}13 \text { Nurses provide enough space for our family to express } \\
\text { feelings }\end{array}$ & 0.753 & 8.2 & 14.5 & 10.1 & 22.2 & 29.5 & 15.5 \\
\hline 14 Nurses show sufficient compassion for our family & 0.657 & 5.8 & 6.8 & 9.7 & 23.2 & 30.4 & 24.2 \\
\hline $\begin{array}{l}15 \text { Nurses provide sufficient positive feedback for our } \\
\text { involvement in care }\end{array}$ & 0.744 & 10.6 & 14.5 & 13.0 & 15.5 & 30.0 & 16.4 \\
\hline 16 Nurses show sufficient interest in our family affairs & 0.852 & 10.6 & 12.6 & 13.0 & 18.8 & 30.0 & 15.0 \\
\hline $\begin{array}{l}17 \text { Nurses show sufficient appreciation for family involve- } \\
\text { ment in the patient's care }\end{array}$ & 0.835 & 9.7 & 10.6 & 8.7 & 20.8 & 32.9 & 17.4 \\
\hline $\begin{array}{l}18 \text { Nurses show sufficient consideration for the well-being } \\
\text { of our family }\end{array}$ & 0.856 & 9.7 & 8.2 & 8.7 & 20.8 & 34.3 & 18.4 \\
\hline $\begin{array}{l}19 \text { Nurses show sufficient interest in how our family copes } \\
\text { with aftercare }\end{array}$ & 0.643 & 12.1 & 11.6 & 12.1 & 16.9 & 33.3 & 14.0 \\
\hline
\end{tabular}

has highlighted the gendered nature of family care work and how little the traditional caregiver role has changed, thus posing a challenge to gender equality despite the large number of women who now work outside the home (54). In our analyses, the trend of double duty was observed as well. Independent of gender equity, our survey showed that half of the family caregivers were still employed and working on an average of 32 hours per week outside of their caregiving role. These families might have fewer people in their neighbourhood whom they can ask for help. Social support networks often consist of healthcare professionals, family members and spouses or partners $(22,55)$.
The factor analysis revealed a three-factor solution according to the social support theoretical framework by Kahn and Antonucci (36), with the dimensions of affirmation, affect and concrete aid and to the FAFHES social support scale $(21,35)$. The psychometric properties were comparable to those of the original questionnaire. The total variance of $79.6 \%$ was equivalent to the Finnish versions' findings ranging from $75.8 \%$ to $82.9 \%(21,35)$, but higher than the accounted variance of $57 \%$ in the Danish version (40). The internal consistency coefficients showed excellent Cronbach's alpha $>0.90$ for all three dimension of social support and was even higher than previous measures, which ranged from 0.71 to 0.95 in 
Table 5 Factor analysis - rotated component matrix

\begin{tabular}{|c|c|c|c|c|c|c|}
\hline \multirow{2}{*}{\multicolumn{2}{|c|}{ Item }} & \multicolumn{3}{|c|}{ Components } & \multirow[b]{2}{*}{ Communalities } & \multirow[b]{2}{*}{ Concepts (Cronbach's alpha } \\
\hline & & 1 & 2 & 3 & & \\
\hline & $\begin{array}{l}\text { We are satisfied with how nurses involved } \\
\text { the care receiver and family in care planning }\end{array}$ & 0.72 & & & 0.77 & Affirmation (0.961) \\
\hline 2 & $\begin{array}{l}\text { Our family received sufficient explanation of } \\
\text { what will happen in the care of our family } \\
\text { member }\end{array}$ & 0.82 & & & 0.84 & \\
\hline $3 r$ & $\begin{array}{l}\text { We received sufficient counselling in matters } \\
\text { related to our family member's care }\end{array}$ & 0.88 & & & 0.88 & \\
\hline 4 & $\begin{array}{l}\text { We have been sufficiently engaged in dis- } \\
\text { cussions about the ill family members' } \\
\text { course of illness }\end{array}$ & 0.75 & & & 0.85 & \\
\hline 5 & $\begin{array}{l}\text { We are satisfied with the amount of discus- } \\
\text { sion about the patient's condition during } \\
\text { care at home }\end{array}$ & 0.81 & & & 0.83 & \\
\hline 6 & $\begin{array}{l}\text { We are satisfied with the amount of discus- } \\
\text { sion about the progress of care }\end{array}$ & 0.73 & & & 0.81 & \\
\hline 7 & $\begin{array}{l}\text { We have received sufficient explanation of } \\
\text { treatment options for our family member }\end{array}$ & 0.71 & & & 0.78 & \\
\hline 8 & $\begin{array}{l}\text { Our family received adequate information } \\
\text { about nutrition of our family member }\end{array}$ & & & 0.66 & 0.75 & Concrete Aid (0.901) \\
\hline 9 & $\begin{array}{l}\text { Our family received sufficient explanation of } \\
\text { what kind of exercise the ill family member } \\
\text { can take }\end{array}$ & & & 0.59 & 0.80 & \\
\hline 10 & $\begin{array}{l}\text { Our family received adequate information } \\
\text { about what to consider regarding to psy- } \\
\text { chological stress of our family member. }\end{array}$ & & & 0.66 & 0.74 & \\
\hline 11 & $\begin{array}{l}\text { Our family has received adequate informa- } \\
\text { tion about the impact the health condition } \\
\text { can have on sexuality }\end{array}$ & & & 0.84 & 0.79 & \\
\hline 12 & $\begin{array}{l}\text { We have been sufficiently encouraged by } \\
\text { nurses to become involved in the care pro- } \\
\text { vided at home }\end{array}$ & & 0.55 & & 0.71 & Affect (0.953) \\
\hline 13 & $\begin{array}{l}\text { Nurses provide enough space for our family } \\
\text { to express feelings }\end{array}$ & & 0.57 & & 0.67 & \\
\hline 14 & $\begin{array}{l}\text { Nurses show sufficient compassion for our } \\
\text { family }\end{array}$ & & 0.72 & & 0.70 & \\
\hline 15 & $\begin{array}{l}\text { Nurses provide sufficient positive feedback } \\
\text { for our involvement in care }\end{array}$ & & 0.68 & & 0.74 & \\
\hline 16 & $\begin{array}{l}\text { Nurses show sufficient interest in our fam- } \\
\text { ily affairs }\end{array}$ & & 0.81 & & 0.84 & \\
\hline 17 & $\begin{array}{l}\text { Nurses show sufficient appreciation for } \\
\text { family involvement in the patient's care }\end{array}$ & & 0.85 & & 0.88 & \\
\hline 18 & $\begin{array}{l}\text { Nurses show sufficient consideration for } \\
\text { the well-being of our family }\end{array}$ & & 0.81 & & 0.84 & \\
\hline 19 & $\begin{array}{l}\text { Nurses show sufficient interest in how our } \\
\text { family copes with aftercare }\end{array}$ & & 0.83 & & 0.87 & \\
\hline & umulative $\%$ of total variance explained & 67.42 & 74.52 & 79.53 & & \\
\hline & genvalues & 12.80 & 1.34 & 0.95 & & \\
\hline \multicolumn{7}{|c|}{ Correlations } \\
\hline & Affirmation with Concrete Aid & & & & & \\
\hline & Affirmation with Affect & & & & & \\
\hline & Affect with Concrete Aid & & & & & \\
\hline
\end{tabular}

*Significance at level $p<0.01$. 
community care setting (7). Item distribution and item correlation were very similar to the Danish study except three items (item 4, 8 and 18) which varied within answers (40).

The questionnaire had to be adapted to a more generic form since the home-dwelling elderly had co-morbid health conditions not limited to only cardiovascular disease. This fact might be an explanation that one item (we have been sufficiently encouraged by nurses to become involved in the patient's care provided at home) was cross loading between the factors concrete aid (0.553) and affect (0.551). The meaning of being encouraged to become involved in the patient's care at home might be different for family caregivers of cardiac patients in hospital. To 'be motivated to become a care partner' as family caregiver caring a family member at home might be more a sense towards the dimension of concrete aid from nurses. In contrast, family caregivers of cardiac patients in hospital might refer item 'to be encouraged to become involved' more to the dimension of affect than to the dimension of concrete aid.

Referring to 'social support' theoretical framework by Kahn and Antonucci (36), the questionnaire operationalised the three dimensions adequately. Referring to the concept of involvement as defined in this article, the questionnaire covers involvement into care process by having an active partnership with nurses very well. While affirmation covers involvement in decision-making, the questions of affirmation address the emotional aspect of being involved as family caregivers. The questionnaire should be customised to more adequately reflect how to be involved in a collaborative way with nurses in hands on care for frail older people living at home. Social support is a very common concept used for social network issues and is less known as concept of getting professional support. But other theoreticians as Kahn and Antonucci (36) defined social support more globally as well. Either they do not specify the relationship between the provider and receiver or actually include professionals and the community as potential sources of social support (56). Therefore, we prefer to rename the questionnaire into 'involvement into care' scale to avoid confusion and be more accurate.

\section{Limitation}

Considering the inclusion criteria that we targeted caregivers of a home-dwelling population over the age of 65 years, the questionnaire might be reliable only for caregivers of elderly persons. Due to caregivers own possible frailty and advanced age, we were confronted with a highly vulnerable caregiver population. Notably, the interest to participate in our study was fairly good. Nevertheless, a fifth of respondents did not fully complete the questionnaire, for reasons not known. One possible explanation might be that the individuals who did not complete the questionnaire did not define themselves as family caregiver. If family members do not identify themselves as family caregiver they would not ask for support (57) and consequently they do not have a need to collaborate with professional nurses.

The PCA with three-factor solution measured a total variance of $79.6 \%$, however the eigenvalue of the third factor - concrete aid - was with 0.95 slightly under 1 which we considered as sufficient because it was higher than the recommended cut-off point of an eigenvalue of $0.70(46,48,49)$. Furthermore, it is recommended to select the number of factors on theoretical criteria rather than to choose components from a variance perspective (46). Therefore, clustering items on factors should be as well conceptually driven.

Alpha value $>0.90$ suggests that some items may be redundant (51). The cognitive debriefing interviews with one women indicated the proximity of some questions, for example appreciation and compassion. The mean inter-item correlation of 0.653 suggests that the focus of the items might be too close. Therefore, a short form checking for redundant items in this questionnaire may be needed to capture the construct of social support or involvement into care more accurately.

\section{Conclusion}

Regardless of the care setting, family members of older care receivers express their need to be supported and to be involved in the care process the world around. The German version of the social support scale from the nursing questionnaire FAFHES is a valid and reliable instrument to assess family perceived support on the three dimensions of affirmation, affect and concrete aid.

The questionnaire is an instrument to assess family caregiver's perceived support from nurses and involvement into care when they both care for a person at home. The instrument should be tested further for its culturally appropriateness in other German-speaking countries and it also should be tested for its sensitivity. It could be a useful tool to assess the perception of family caregivers' involvement in care, pre and post nursing interventions around family involvement.

\section{Acknowledgements}

The authors wish to thank all participating family members and the home health agency (Spitex Zürich Limmat AG) for their collaboration in data collection. We also want to thank Prof. Dr. Thomas Volken for valuable statistical advices, to Susan Schärli and Jessica Gaylord for participating in the translation process of the instrument and to Jessica Gaylord for English editing. 


\section{Author contributions}

Irène Ris had the main responsible for study conceptions/ designs, data collection, data analysis and wrote the manuscript as first author. Wilfried Schnepp critically revised the manuscript for important intellectual content. Romy Mahrer-Imhof contributed as a supervisor for the study conceptions/designs, analysis and critical revisions. All authors have given their final approval of the version to be published.

\section{References}

1 Bloom DE, Boersch-Supan A, McGee $\mathrm{P}$, Seike A. Population aging: facts, challenges, and responses. Benefits Compens Int 2011; 41: 22.

2 Rechel B, Grundy E, Robine J-M, Cylus J, Mackenbach JP, Knai C, McKee M. Ageing in the European union. Lancet 2013; 381: 1312-22.

3 Tarricone R, Tsouros AD. Home care in Europe: the solid facts. 2008, WHO Regional Office Europe.

4 Soodeen R, Gregory D, Bond JB Jr. Home care for older couples: "it feels like a security blanket...". Qual Health Res 2007; 17: 1245-55.

5 Bonsang E, Schoenmaeckers J. Longterm care insurance and the family: does the availability of potential caregivers substitute for long-term care insurance. In Ageing in Europe-Supporting Policies for an Inclusive Society. (Börsch-Supan A, Kneip T, Litwin H, Myck M, Weber G eds), 2015, De Gruyter, Germany, 369-80.

6 Büscher A, Astedt-Kurki P, Paavilainen E, Schnepp W. Negotiations about helpfulness - the relationship between formal and informal care in home care arrangements. Scand $J$ Caring Sci 2011; 25: 706-15.

7 Hautsalo K, Rantanen A, AstedtKurki P. Family functioning, health and social support assessed by aged home care clients and their family members. J Clin Nurs 2013; 22: 2953-63.

8 Gantert TW, McWilliam CL, WardGriffin C, Allen N. Working it out together: family caregivers' perceptions of relationship-building with in-home service providers. Can $J$ Nurs Res 2009; 41: 44-63.

9 Collins LG, Swartz K. Caregiver care. Am Fam Physician 2011; 83: 1309.
10 Federal Statistical Office (Bundesamt für Statistik) [BSF]. Gesundheit Taschenstatistik 2016. Neuchatel: Schweizerische Eidgenossenschaft Eidgenössisches Departement des Inneren EDI.

11 Palonen M, Kaunonen M, AstedtKurki P. Family involvement in emergency department discharge education for older people. $J$ Clin Nurs 2016; 25: 3333-44.

12 Andershed B, Ternestedt BM. Involvement of relatives in care of the dying in different care cultures: development of a theoretical understanding. Nurs Sci Q 1999; 12: 45-51.

13 Lin ML, Pang MCS, Chen CH. Family as a whole: elective surgery patients' perception of the meaning of family involvement in decision making. J Clin Nurs 2013; 22: 271-8.

14 Petriwskyj A, Gibson A, Parker D, Banks S, Andrews S, Robinson A. Family involvement in decision making for people with dementia in residential aged care: a systematic review of quantitative literature. Int $J$ Evid Based Healthc 2014; 12: 64-86.

15 Funk L, Stajduhar K. Analysis and proposed model of family caregivers' relationships with home health providers and perceptions of the quality of formal services. J Appl Gerontol 2013; 32: 188-206.

16 Piamjariyakul U, Smith CE, Werkowitch M, Elyachar A. Part I: Heart failure home management: patients, multidisciplinary health care professionals and family caregivers' perspectives. Appl Nurs Res 2012; 25: 239-45.

17 Lévesque L, Ducharme F, Caron C, Hanson E, Magnusson L, Nolan J, Nolan M. A partnership approach to service needs assessment with family caregivers of an aging relative living at home: a qualitative analysis of the experiences of caregivers and practitioners. Int J Nurs Stud 2010; 47: 876-87.

18 Bragstad LK, Kirkevold M, Hofoss D, Foss C. Informal caregivers' participation when older adults in Norway are discharged from the hospital. Health Soc Care Community 2014; 22: 155-68.

19 Laidsaar-Powell R, Butow P, Bu S, Charles C, Gafni A, Fisher A, Juraskova I. Family involvement in cancer treatment decision-making: a qualitative study of patient, family, and clinician attitudes and experiences. Patient Educ Couns 2016; 99: 114655.

20 Martire LM. The" relative" efficacy of involving family in psychosocial interventions for chronic illness: are there added benefits to patients and family members?. Fam Syst Health 2005; 23: 312.

21 Astedt-Kurki P, Tarkka MT, Rikala MR, Lehti K, Paavilainen E. Further testing of a family nursing instrument (FAFHES). Int $J$ Nurs Stud 2009; 46: 350-9.

22 Demidenko J, Routasalo P, Helminen M, Åstedt-Kurki P, Paavilainen E, Suominen T. Social support received by the family of older patients in emergency department: a cross-sectional study. Clin Nurs Stud 2017; 6: $1-8$.

23 Heacock P. Cambridge academic content dictionary. 2009, Cambridge University Press.

24 Chou KR. Caregiver burden: a concept analysis. J Pediatr Nurs 2000; 15: 398-407.

25 Fast CT, Houlihan D, Buchanan JA. Developing the family involvement questionnaire-long-term care: a measure of familial involvement in the 
lives of residents at long-term care facilities. Gerontologist 2018: 1-14.

26 Purden M, Mustafa SS, Looper KJ, Zelkowitz P, Group MEAR, Baron M. Caregiving appraisal and disease activity in early inflammatory arthritis. Scand J Caring Sci 2013; 27: 156-64.

27 Benzein E, Johansson P, Årestedt KF, Berg A, Saveman B-I. Families' Importance in Nursing Care: nurses' Attitudes-An instrument development. J Fam Nurs 2008; 14: 97-117.

28 Saveman B-I, Benzein EG, Engström $\AA \mathrm{H}$, Årestedt K. Refinement and psychometric reevaluation of the instrument: families' importance in nursing care-nurses' attitudes. J Fam Nurs 2011; 17: 312-29.

29 Simpson P, Tarrant M. Development of the family nursing practice scale. $J$ Fam Nurs 2006; 12: 413-25.

30 Stajduhar KI, Funk L, Roberts D, McLeod B, Cloutier-Fisher D, Wilkinson C, Purkis ME. Home care nurses' decisions about the need for and amount of service at the end of life. J Adv Nurs 2011; 67: 276-86.

31 Al-Mutair AS, Plummer V, O'brien A, Clerehan R. Family needs and involvement in the intensive care unit: a literature review. J Clin Nurs 2013; 14: 1805-17.

32 Shin DW, Cho J, Roter DL, Kim SY, Sohn SK, Yoon MS, Kim YW, Cho B, Park JH. Preferences for and experiences of family involvement in cancer treatment decision-making: patient-caregiver dyads study. Psycho-Oncology 2013; 22: 2624-31.

33 Sveinbjarnardottir EK, Svavarsdottir EK, Hrafnkelsson B. Psychometric development of the Iceland-Family Perceived Support Questionnaire (ICE-FPSQ). J Fam Nurs 2012; 18: 328-52.

34 Maijala H, Åstedt-Kurki P. From substantive theory towards a family nursing scale. Nurse Res 2009; 16: 29-44.

35 Astedt-Kurki P, Tarkka MT, Paavilainen E, Lehti K. Development and testing of a family nursing scale. West J Nurs Res 2002; 24: 567-79.

36 Kahn RL, Antonucci TC. Convoys over the life course: attachment, roles, and social support. In: Baltes
$\mathrm{PB}$, Brim O, editors. Life-span development and behavior. 3. 1980, Academic Press, New York. pp. 253-86.

37 Tarkka MT, Paavilainen E, Lehti K, Åstedt-Kurki P. In-hospital social support for families of heart patients. J Clin Nurs 2003; 12: 736-43.

38 Paavilainen E, Lehti K, Åstedt-Kurki P, Tarkka M. Family functioning assessed by family members in Finnish families of heart patients. Eur $J$ Cardiovasc Nurs 2006; 5: 54-59.

39 Hakio N, Rantanen A, Åstedt-Kurki $\mathrm{P}$, Suominen T. Parents' experiences of family functioning, health and social support provided by nurses-A pilot study in paediatric intensive care. Intensive Crit Care Nurs 2015; 31: 29-37.

40 Østergaard B, Pedersen KS, Lauridsen J, Nørgaard B, Jeune B. Translation and field testing of the family functioning, family health and social support questionnaire in Danish outpatients with heart failure. Scand $J$ Caring Sci 2017: 1-13.

41 Beaton DE, Bombardier C, Guillemin F, Ferraz MB. Guidelines for the process of cross-cultural adaptation of self-report measures. Spine (Phila $\mathrm{Pa}$ 1976) 2000; 25: 3186-91.

42 Polit DF, Beck CT. Nursing research: generating and assessing evidence for nursing practice, 9th edn. 2012, Lippincott Williams \& Wilkins, Philadelphia.

43 Wright LM, Leahey M. Nurses and families: a guide to family assessment and intervention, 6th edn. 2013, F.A. Davis, Philadelphia.

44 Kuckartz U, Rädiker S, Ebert T, Schehl J. Statistics: an understandable introduction (Statistik: eine verständliche Einführung). Springer-Verlag.

45 Schafer JL, Graham JW. Missing data: our view of the state $n$ the art. Psychol Methods 2002; 7: 14 =

46 Tabachnick BG, Fidell LS. Mulitvariate Analysis. 6 ed. 2013. Pearson Education, Boston, MC. 2014.

47 West SG, Finch JF, Curran PJ. Structural equation models with nonnormal variables: Problems and remedies. 1995.

48 Bortz J, Schuster C. Statistics for human and social science, 2011
(Statistik für Human-und Sozialwissenschaftler: Limitierte Sonderausgabe 2011): Springer, Berlin, Heidelberg.

49 Watson R, Thompson DR. Use of factor analysis in Journal of Advanced Nursing: literature review. $J$ Adv Nurs 2006; 55: 330-41.

50 Mooi E, Sarstedt M. Cluster analysis. A concise guide to market research. The Process, Data and Methods Using IBM SPSS Statistics, 2011, Springer, Heidelberg, Dordrecht, London, New York.

51 Tavakol M, Dennick R. Making sense of Cronbach's alpha. Int J Med Educ 2011; 2: 53.

52 Fringer A, Kiener L, Schwarz N. Situation of family caregivers in the city of St.Gallen (SitPA-SG). Research project commissioned by the city of St.Gallen. final report, 2013. (Situation pflegender Angehöriger in der Stadt St.Gallen (SitPA-SG). Forschungsprojekt im Auftrag der Stadt St.Gallen. Abschlussbericht). Institut für Angewandte Pflegeforschung (IPW-FHS), FHS St.Gallen.

53 Imhof L, Naef R, Wallhagen MI, Schwarz J, Mahrer-Imhof R. Effects of an advanced practice nurse in-home health consultation program for community-dwelling persons aged 80 and older. J Am Geriatr Soc 2012; 60: 2223-31.

54 Bookman A, Harrington M. Family caregivers: a shadow workforce in the geriatric health care system? J Health Polit Policy Law 2007; 32: 1005-41.

55 Verver D, Merten H, Robben P, Wagner C. Care and support for older adults in The Netherlands living independently. Health Soc Care Community 2018; 26: e404-14.

56 Hupcey JE, Morse JM. Can a professional relationship be considered social support? Nurs Outlook 1997; 45: 270-6.

57 Mischke C. Resources of family caregivers: Development and testing of an assessment instrument, 2012. (Ressourcen von pflegenden Angehörigen: Entwicklung und Testung eines Assessmentinstruments, 2012). Hpsmedia, Hungen. 